\title{
SOCIODRAMA AND ROLE-PLAY: THEORIES AND INTERVENTIONS
}

\author{
Cybele Maria Rabelo Ramalho1,* [D
}

\begin{abstract}
This article presents the sociodramatic method developed by Jacob Levy Moreno (origin, definitions, unfolding, characteristics, modalities, objectives), differentiating it from psychodrama, as well as presents the role-play, in sociopsychodramatic practice, especially for socioeducational purpose. It illustrates the application of these modalities with brief accounts of the author's experience with groups in sociodramatic acts and processes. It reports an institutional experience with retired elderly citizens, held for six months, using as initiators, tales for adults that bring archetype themes common to this age group; another experience with several thematic workshops, focused on the development of female roles, using the technique of the living museum; finally, an experience of supervision with graduation students, held during two university terms.
\end{abstract}

KEYWORDS: Sociodrama; Role-Play; Supervision; Sociopsychodrama.

\section{SOCIODRAMA E ROLE-PLAY: TEORIAS E INTERVENÇÕES}

\section{RESUMO}

Este artigo apresenta o método sociodramático desenvolvido por Jacob Levy Moreno (origem, definições, desdobramentos, características, modalidades, objetivos), diferenciando-o do psicodrama, bem como apresenta o role-play, na prática sociopsicodramática, especialmente para fins socioeducativos. Ilustra a aplicação dessas modalidades com breves relatos da experiência da autora com grupos em atos e processos sociodramáticos. Relata-se uma experiência institucional com idosos aposentados, realizada durante seis meses, utilizando como iniciadores, contos para adultos que trazem temas arquetípicos comuns a essa faixa etária; outra experiência com várias oficinas temáticas, voltadas para o desenvolvimento de papéis femininos, utilizando a técnica do museu vivo; por fim, uma experiência de supervisão com alunos de graduação, realizada durante dois períodos universitários.

PALAVRAS-CHAVE: Sociodrama; Role-Play; Supervisão; Sociopsicodramática.

\section{SOCIODRAMA Y JUEGO DE ROLES: BASES TEÓRICAS E INTERVENCIONES}

\section{RESUMEN}

Este artículo presenta el método sociodramático desarrollado por Jacob Levy Moreno (origen, definiciones, desdoblamiento, características, modalidades, objetivos), diferenciándolo del psicodrama, así como presenta el juego de roles, en la práctica sociopsicodramática, especialmente con fines socioeducativos. Ilustra la aplicación de estas modalidades con breves relatos de la experiencia del autor con grupos en actos y procesos sociodramáticos. Reporta una experiencia

1.Clínica Profissionais Integrados - Aracaju (SE), Brazil.

*Corresponding author: cybeleramalho@gmail.com

Section Editor: Michael Wieser

Received: Jun. 01, 2020 | Accepted: Dec. 29, 2020 
institucional con ancianos jubilados, realizada durante seis meses, utilizando como iniciadores, cuentos para adultos que traen temas arquetipos comunes a este grupo de edad; otra experiencia con varios talleres temáticos, centrados en el desarrollo de roles femeninos, utilizando la técnica del museo vivo; finalmente, una experiencia de supervisión con estudiantes de graduación, realizada durante dos períodos universitarios.

PALABRAS-CLAVE: Sociodrama; Role-Play; Supervisión; Sociopsicodrama.

\section{INTRODUCTION}

In the Morenian approach, the human being is seen as a person inserted in a world ordered by cultural conserves (with its collective laws and ideologies), tending to repeat his relational experiences in a growing process of automation, which keeps him away from spontaneity and freedom, additionally sickening his personal relationships. On the other hand, the person is seen as a potential genius, who, through his creative spontaneity, paradoxically searches for the encounter and telic relations, and also for existential transcendence in his relations with the world.

In the face of this contradiction, Jacob Levy Moreno created socionomy in order to promote the transformation of social groups by developing methods, concepts and instruments with a view of learning about the social tensions in the here and now, in status nascendi, a movement which involves everyone in coparticipation and coresponsibility. This socionomic process is particularly effective within the socioeducational context in addition to the widely known therapeutic psychodrama.

This article aims to be faithful to Moreno's statement, which characterizes that the use of psychodrama only in private offices would be like using an airplane to go around the corner. Next, it defends the importance of using sociodrama and role-playing in the socioeducational context. Finally, it will present and discuss the content pertaining to both approaches and illustrate the practice and results of therapeutic experiences.

\section{SOCIODRAMA}

The Brazilian sociologist Guerreiro Ramos (1915-1982) brought sociodrama to Brazil through his social work at the Teatro Experimental do Negro (state of Rio de Janeiro) with an emphasis on race relations. In his publications in the newspaper $O$ Quilombo, defined sociodrama as a method of eliminating prejudices or stereotypes to free an individual's consciousness from social pressures (Malaquias,2007). In the following years, the influence of the strong military dictatorship pushed the sociodramatic method into the background and the use of psychodrama in Brazil turned its attention to the psychotherapeutic field resulting in missing the potential and focus of the time. In the beginning of 1980s, psychodrama developed a sociopolitical and educational focus, and new sociodramatic practices emerged. Such practices treated sociocultural, political, existential, and human rights issues in wide and diverse ways (Figusch, 2010).

Similar to psychodrama, sociodrama was created by Moreno to deal with sick interpersonal relations and social systems, both (with group psychotherapy), composing his sociatry. Beginning in 1946, Moreno had already defined sociodrama as a profound action method to approach intergroup relations and collective ideologies differentiating it from psychodrama (Fox, 2002). Although both were specific sociatric instruments (group treatment methods), sociodrama would be more centered on the concepts of role theory, spontaneity theory and social bonding anthropology (Menegazzo et al., 1995).

While the group approach in psychodrama is directed to a private group of individuals, the real subject of sociodrama is the group itself. Therefore, the goal of sociodrama is to work on social issues or themes, with a main focus on the sociocultural roles to produce a social catharsis. Moreno pointed out that sociodrama centered its attention on collective denominators and not on individual interests or private issues. 
We call attention here to some differences and similarities between psychodrama and sociodrama. Psychodrama derives from an internal reality (a private world) that seeks its expression in the collective drama, leading to the movement "from the inside out" in an attempt to make the subjective experience an objective experience; sociodrama, in turn, derives from social happenings, collective relationships, allowing each individual to come forward by means of action or subjectively through a reality common to all, leading to the movement "from the outside in", which is an attempt to make the objective reality a more subjective reality.

In psychodrama, the group is structured through a protagonist that arises spontaneously in the warming up process within the dramatic context, and later, during the sharing of the session, when the participants manifest their singularities. Psychodrama is desired by individuals who present conflict symptoms and as psychodrama's working axis lays on tele, transference and the matrix of identity, individuals can work on their resignification.

In sociodrama, group members interact and share from an initial stimulus that may be factual or an understood social reality. In general, the work starts with the transition from the social context to the group with a focus on group interaction; scenes are developed and dramatized, they perform soliloquy and form subgroups according to common interests. Later, members perform in new scenes or take on roles of new characters. Some scenes are denser and reflect the group's counconscious state. Thus, the work done with preformed or preexisting groups is considered sociodramatic.

The working axis of sociodrama is centered on group interaction and on its production of a theme, thus, in group contemplation, new meanings are developed, new interactions are supported, and new subjective relationships are formed.

Although these differences are broad, these two sociatric methods show some similarities, and their differential threshold is not always clear. Both psychodrama and sociodrama work with social and psychodramatic roles. The latter is the spontaneous-creative role that results from the deterioration of a social role by uplifting the inherent subjective experience (Mascarenhas \& Pinto, 1990). Eventually, objectivity influences subjectivity, and vice versa, both in sociodrama and psychodrama. The individual formed through these roles, in the discrimination and articulation of social and psychodramatic roles. This formation is necessary for the development of tele, speech and spontaneity, important values in the psychosociodramatic processes. Thus, there is no opposition between the social and the psychological dimensions, since they are complimentary and interdependent. Finally, psychodrama and sociodrama complementary and convergent instruments when dealing with the "existential being".

In general, the practical work may become sociopsychodramatic. However, one needs to measure the predominance of the focus on the social or psychotherapeutic work, which depends on the working context and the contract established with the group. According to Mascarenhas and Pinto (1990), there is a combination of a social and a psychodramatic perspective in the use of the technique of dramatic multiplication with groups, that is, the two strategic axes mentioned above are mixed: 1) Tele - transference - identity matrix; 2) Interaction - collective production - crossings.

Dramatic multiplication is a technique created by the Argentine psychodramatists Kesselman and Pavlovsky, in 1989, which comprises group disposition as a sense production machine, integrating the contributions of Moreno to those of schizoanalysis, defending the group as traversed by the various subjectivities of its members, in a constant creative state. This technique consists of leading the group protagonist to a descriptive dramatization (often making use of the basic techniques), which is the original scene. Then, each member of the group starts to dramatically multiply this first scene, transforming it, expanding it, amplifying it, and starting from the resonances of a single performance by one person, a production of several authors is constructed. This resonance group phenomenon is central for the production of new meanings, in the following consonant and resonant scenes that are created (Mascarenhas \& Pinto, 1990; Kesselman \& Pavlovsky, 1989; Fernández, 2015).

In the case of socioeducational interventions, a sociodramatic act is contracted in agreement with the group so as to work its sociocultural moment and roles. This group conduct may also generate some psychodramatic effects. As a directing strategy (Knobel, 2020), sociodrama focuses on the spontaneous creation of collective dramatizations, which may reveal the unconscious fantasies of the collective imaginary (not only those emerging from the group's counconscious state, but also, for example, the myths and the archetypes of the collective unconscious). 
According to Marra (2004), sociodrama can be used as a psychopedagogical method to apply in group work with the goal of facilitating the learning of roles, ideas, concepts and behaviors through socioeducational experiences. By the use of sociodrama, in this context, it is possible to intervene in the relations of natural groups formed spontaneously (couples, families, communities etc.) or working and learning groups. Some of the purposes of sociodrama are:

- It points to the social roles that interact in the group's common activities;

- It allows the group to visualize its conflicts and make them emerge in order to reach an understanding;

- It clarifies intergroup relations and shared ideologies and values;

- It allows the psychological investigation of the social roles of those involved.

Whether latent or complex group conflicts, when explored through sociodramatic techniques, will emerge and be clarified. It is important to identify the social relationships and not contaminate them with personal distortions. Social relationships often go through a filtering process based on perceptive projections and distortions that can affect the continuity and the development of greater telic sensitivity.

According to Menegazzo et al. (1995), there are two types of sociodrama:

- Institutional (used in primary prevention and applied in working and learning groups);

- Therapeutic (used in secondary prevention), in which sociodrama can be included for couples and families as natural groups (Marra, 2004).

Therefore, two types of sociodrama can be applied:

- The one that arises from the group's demand (the theme emerges at the moment);

- Thematic sociodrama (the theme is already defined, without a script, since it springs from group interaction after the warming up process around an initial theme).

Sociodrama originated in the roots of the spontaneous theater, which, in turn, gave birth to the living newspaper, axiodrama, the play back theater, dramatic multiplication, the theater of the oppressed and many more recent sociodramatic modalities. Some authors, including Mezher (2002), even consider axiodrama a special sociodramatic approach, which aims at a predetermined thematic axis with ethical and social values and the goal of reevaluating or replacing them. At first, the director, in the axiodramatic approach, searches for scripts or initial stimuli for the groups' warming up processes and the development of social value provocateurs to unveil taboos, beliefs, prejudices and stereotypes of cultural conserves. Thus, when the focus is axiodramatic as well as political-ideological, reflecting a social drama, the axiodrama may be considered a type of sociodrama or "axiosociodrama" (Mezher, 2002).

According to Mezher (2002), axiodrama deals with religious, ethical and cultural values in a spontaneous-dramatic way. It is a sociatric method, in which, the director, as a social transformation agent, handles members' ethical, religious and cultural values through a dramatic experience, so that they are able to reveal and confront their old and new value patterns, to promote change, and consequently be in a different world. Axiodrama is applied individually or in groups, using the entire theoretical-practical arsenal of psychodrama and it can be used with a predefined theme, or not. As for ethnodrama, Moreno created it as a synthesis of psychodrama with research on ethnic problems (black and white, Arabs and Jews, etc.). In his life, Moreno worked mainly to combat prejudice against Jews by using ethnodrama (Mezher, 2002).

Sociodrama can be procedural or it can be performed in a single event, constituting a therapeutic act. Thus, it can be applied in the most distinct contexts: in education, on the streets, in community practices, in organizational areas, with families, couples, in sociopolitical works, in the prevention of HIV, in all sorts of human rights defense groups and as an investigative instrument in action research. 
However, the real subject of sociodrama is the group; therefore, it is not limited by a special number of individuals. The group size and group members are not relevant in sociodrama as the entire group is put on stage to work on issues. The goal of sociodrama is to elicit the socio-historical-cultural rationale through dramatic methods, assuming that every human being is a role-player who has his personal and cultural characteristics (socially imposed). Through the sociodramatic work in microreality, the macroreality of the social context is made explicit as it is contained in the social actors' references involved in it (Ramalho, 2010).

Therefore, sociodrama is a very useful method in socioeducational and community work. It is an instrument that: raises awareness of the issues of a particular community; stimulates common repositioning and channels of solidarity; favors popular demonstrations; and promotes psychosocial interventions through strategies built up by the group (Marra, 2004).

In sociodrama, through its spontaneous role-playing techniques, everyone shares their subjective impressions, participates in the construction of the work, puts oneself in the place of the other, structures their interpersonal relationships, understands historical-cultural determinations, networks and communication standards, develops coresponsibility for the collective process and can become social agents of change (Marra, 2004).

In the application of sociodrama to socioeducational institutions, the basic phases of the method (warming up process, dramatization and sharing) are followed as well as its five instruments (protagonist, director, setting, audience and auxiliary egos) and the articulation of the three contexts (social, group and sociodramatic). Care must be taken with the special handling of the audience so as not to leave the social role in question, incorporating it to other personal roles. For example, the participant should always speak in the role of boss, supervisor, employee or customer of the company, exploring what is seen in the scene and in the dramatic space of the here and now.

\section{THE USE OF SOCIODRAMA AS SOCIOTHERAPEUTIC ACTS}

Two sociodramas will illustrate the practice. The first, carried out in an institutional context, was a sociodrama with retired senior citizens. The sociodrama was based in fairy tales for adults (Chinen, 1989), as initiators in a sociodramatic proposal, whose focus was the development of the emerging role of senior citizens, in a series of open meetings that lasted six months. These short stories portray specific archetypal issues of this age group. which include the resignification of predictable losses or mourning, the encounter with emerging contents of the Shadow (personal and collective), the review of the Persona (which undergoes a significant process of transformation), the confrontations with sickness and death, the search for a true Self, etc. (Ramalho, 2010). Specific fairy tales were selected for the warming up process that deal with the elderly's archetypal journey. The tales were read and dramatized, producing rich expressions and transformations.

Another example of is the sociodrama of the feminine. It was held in open workshops, working on the multiple female roles, using sculptures or images as initial stimuli. In these thematic sociodramas, sculptures or artistic images expressing archetypal themes of the feminine were presented, building up the living museum sculptures and artistic images that express archetypal themes of the feminine.

The living museum is a technique developed by Ramalho (2016), inspired by the Jungian psychodrama (Gasseau \& Gasca, 1991), where the group is invited to enter a magical atmosphere of an imaginary museum. Real artistic pieces are exhibited as visual initiators, and from the free choice of one among many works, the participant begins to dialogue with the piece, using this emotion on the creation of a new title and a scenic narrative. Next, subgroups can be formed by identification with emerging themes, for dramatically create and present their scenes. In the end it is proposed the creation of a collective scene, with the integration of emerging themes. From the group resonances with the use of this technique, it enables a collective review of the female roles in Brazilian culture and a consequent evaluation of the paths of resistance, deepening and transformation in the effective performance of these roles.

In the specific case of the sociodrama of the feminine, with the living museum supporting aid technique (Ramalho, 2016), for instance, clients attend the session attracted by the theme, so they are already previously warmed up in their subjectivity. After a brief warming up process to create a group context and promote integration in a spontaneous atmosphere, sculptures or artistic images of this feminine in its multiple faces, age groups and contexts, all previously selected, are distributed to 
warm up the group. First images are selected by the group based on their main priority issues. Second, characters, stories or scenes are created and incorporated. Third, subgroups reflect on them and perform dramatic scenes that show the associations and analogies they have made with their real, everyday lives, upon reflecting on the artistic image or piece. Fourth, it is requested that, in addition to the scenes based on their reality, the group as a whole builds up and dramatizes a single scene that represents and synthesizes the group's desire for change and transformation. Finally, the most representative scenes elected by the large group are explored and consider the collective issues or dramas exposed there. In general, the reflections made in the sharing of feelings refer to sociocultural roles, values and archetypal pre-dispositions of the female gender, present in everyday scenes and dramas.

The experience with the thematic sociodramatic method and the use of fairy tales and artistic images and pieces as a warming up process enables the recreation of social roles (in this case, roles of the elderly and women) promoting a greater flow of spontaneity in the performance of these roles. It also considers beliefs and prejudices toward cultural conserves that affect these oppressed categories, even operationalizing collective change processes. Besides, when making subjective emerging issues from the group's counconscious state more vivid, sociodrama favors the emergence of material from the collective unconscious (of archetypal nature), at the level of concretization of the performance of existential roles.

\section{ROLE-PLAY}

Role-play is a dramatic supporting instrument developed by J.L. Moreno to improve the learning of a professional role or any social role that one wants to optimize. It is an essential sociodynamic technique and it is widely used in teachinglearning situations, or in what he called didactic psychodrama (Moreno \& Moreno, 2006).

The expression "role-player" is a literal translation of the German word rollenspieler, initially used by J.L. Moreno. The English term was universalized and kept in Portuguese because it contained, in a single word, the concepts of playing, acting and moving, the characteristics of the technique (Kaufman, 1992).

When using role-play, the director should focus on the role that is being addressed, and its complementary roles, as requested by the contract (for example, therapist-client, teacher-student, etc.), without crossing over into other roles which are not in play. Exceptionally, the director can introduce others roles, if the contract is renewed with the group, according to ethical limits.

For Moreno, role-play is a sociodramatic resource that uses the "as if" to develop spontaneous-creative roles, but first it should go through the three primary developmental phases of any role: 1) Role-taking (the taking or acceptance of a role with its prescribed and organized characteristics), which gives rise to the role-taker;2) Role-playing (when the individual learns how to play with the role and uses a certain amount of freedom), which gives rise to the role-interpreter; 3) Rolecreating (when the individual is freer and has more initiative to create in the role), which gives rise to the role-creator. This final phase starts with the taking of a social role and it becomes more active in the sociodramatic context, that is, spontaneous-creative.

How does this technique work? After a fundamental warming up process to contextualize the group and choose the protagonists and auxiliary egos, a complementary role taking process begins since the protagonist is more familiar with it. Next, the individual will perform the other role that he should structure and recognize after several role reversals (with the help of an auxiliary ego). The objective is to achieve a spontaneous and adaptive flow, with a good level of creativity, in addition to a broader perception of the difficulties that the individual presents in the performance of this role.

Role-play is very useful for working with resisted and impaired or restricted roles, as well as for supervising professional relationships such as doctor-patient, teacher-student, etc. According to Kaufman (1992), the purpose of role-play is "the objective perception of the feelings and attitudes of others, who play the counter role, and the most appropriate response to the situation" (p. 193). It is very important to understand the tension and anxiety caused by a given role, in addition to clarifying the defense mechanisms employed in it.

The use of role-play in the classroom, for instance, may open up possibilities for new learning, based on the spontaneitycreativity axis, breaking with conduct stereotypes or pre-fixed behaviors of the cultural conserve. One can even speak of a 
kind of "role therapy" when working with role-play for the development of a particular professional or social role. According to Moreno \& Moreno (2006), through role-play:

Students learn to take on both the patient role and their own professional roles. Training situations are structured according to the typical conflicts they are used to or those they have the opportunity to face professionally. Several versions can be represented by the various students, so that they can deal with an unruly patient (p. 392).

Inspired by Morenian words, role-play has been used as a fundamental working axis for teacher-supervisor of psychodrama trainees. Role-play was applied to develop research in the classroom, since it is an illustrative experience and relevant learning to the psychodramatist psychotherapist's role as it will be summarized below.

\section{The use of role-play in supervision}

The goal of this research was to evaluate and reflect on the methodology developed during the supervision of Psychology graduation students. The socionomic theory and the sociodramatic method were used focusing on the development of the role of the psychotherapist, the sociodynamics of the therapist-client professional relationship, the role-play technique and dramatic games. Evaluation and analyzes of the results of the development of this supervisory method through a questionnaire applied to ten trainees under supervision were carried on.

The supervisory method used was an educational sociodramatic technique (Romaña,1987). In this method, the trainee and his group peers gained self-knowledge as they worked together. Each trainee found opportunities to offer his/her contribution by expressing his/her experience in relation to the theme in a dialectic process. It valued the trainee's previous acquisitions, as the stimulation of what is already known may expand in the group and enable new ways of organizing knowledge through the dramatic process.

The technique is used in order to exemplify knowledge, find alternative solutions to the issues presented, develop new roles, prevent anxiety situations, sensitize the group as a class, elaborate changes and evaluate the group's work. In role-play, this supervisory method allows the teacher-supervisor to verify the applicability of the knowledge that has been incorporated in the educational routine (through lecture or discussion classes, group research work, etc.) in a "living" situation, to fix the mistakes or distortions that have been made and to understand the emotional aspects involved in the acquired knowledge, etc.

On the other hand, it is possible to experience a relationship with trainees in a horizontal perspective, to be with them and never above them, as this posture aims at the exchange, intersubjectivity and reciprocal evaluations, favoring telic perception in the trainer-trainee relationship. Supervision can be considered to be an articulating context, where the trainee can integrate his/her various theoretical experiences with the clinical experience as a psychodramatist. This experience took place in a public university, in the last two periods of the Psychology course, where the author was trainer and supervisor of a group of 12 students. The entire process reported here lasted 8 to 10 months (120 hours) of supervision, subdivided into three major stages:

- Role-taking: Corresponds to the first 45 days of supervision, associated with readings and group discussion of the theoretical review content. In this initial stage, including the warm-up of the role of the therapist, worked with dramatic games with a focus on the anxiety and expectations involved. The thematic sociodramatic experience strategy was applied to investigate the emerging role of the therapist and the anxiety related to the encounter with the imaginary and feared client of each one, that is, the encounter with the internalized imaginary therapist of each one. The matrix of emergence of this role, the mythical scenes that the trainee maintains in relation to the figure of the therapist, that is, where the role of the therapist arises in the life story of each trainee were investigated. In this stage of the supervision, technical, ethical and behavioral aspects were also discussed, delving into the individual and collective denominators of the role of the therapist. Dramatic strategies complemented 
by expressive techniques, such as making/drawing the "shield" or "emblem" of the internalized therapist of each one or making/drawing images or sculptures representing this particular role, among others were applied. Other possible dramatic experiences for this stage: a future projection of the first interview or the projection of some imaginary situations feared in the therapeutic setting.

- Role-playing: Begins when the trainees are already seeing clients and supervision is focused on the performance of the ongoing role. In group supervisory sessions, the trainee reports his clinical case insights and difficulties and then the trainer-supervisor proposes that he take on the role of the client and then they change roles. In role-play, the trainee experiences to take on the role of his client and then change roles with him; he presents the case to the other trainees and investigates how he experiences both roles, discovering the dynamic nature of the relationship he establishes with his client, the telic aspects and the emerging ones, etc. The other trainees act as "auxiliary egos", taking on the roles of therapists, clients and sometimes members of the group. It is in role-play that the basic psychodrama techniques such as mirroring, doubling, soliloquy and role interview are used. Role-play takes place with the help of auxiliary egos to introduce the client and to investigate his subjectivity, to find out possible lines of work, transference and resistance in the relationship, etc.

- Role-creating: This step is reached in the third stage of the supervisory process, that is, the possibility of creating and recreating a role. According to Calvente (2002):

[...] this is achieved when the trainee identifies himself with his role; he can perform it spontaneously and experience it by integrating his self to it. That allows him to perform it in his own style, with a much lower level of anxiety and greater spontaneity-creativity (p. 113).

Trainees are supposed to achieve that stage in approximately ten months. However, not all of them do it because each one has their own pace; their own growth period and their own level of spontaneity-creativity for that role. In order to reach that stage, it is fundamental that the trainer-supervisor exercise his role, involving tele and spontaneitycreativity in relation to its complementary role, the trainee. The relationship between a trainer-supervisor and a trainee should be spontaneous, creative and adequate for any special circumstance that shows up at each moment.

Assessing the learning levels of the role of the psychotherapist (role-taking, role-playing and role-creating), especially in the results of this research, it was observed the constant use of the role-play technique in supervision, proving its effectiveness in psychodramatists' role training in educational practice.

All the trainees concluded that the training and the specific use of role-play in their classes enabled their awareness of the difficulties of the role of the therapist. They were able to recognize feelings involved in their relationships with clients and the interference of these feelings in the therapeutic process. Although $65 \%$ of trainees feel partially prepared to play the role of the therapist at the end of the supervision, and only $35 \%$ feel effectively prepared, all of the students have stated that the supervisory method contributed to defining their working style, improving their clinical knowledge and their creative ability in the performance of the role of the psychodramatist.

\section{FINAL CONSIDERATIONS}

Finally, it must not be forgotten that the functions of a psychodramatist, who work in socioeducational contexts are: to make use of instruments that enable the perception of complementary roles; to understand the psychological context within the pedagogical context; and, to understand the previous contexts within a broader social context, so that an individual can recognize himself in his social relationships as a whole. He will develop educational actions that combine "to feel" and "to think" allowing a single and creative manifestation. However, his work with sociodrama and role-play has definite objectives and procedures. 
Role-play should not be seen as mere role-training, since it is essential that roles be created and recreated, according to the Morenian approach, as well as new ways of cultural and personal subjectivation. Nevertheless, it is important to highlight that it also works with emotions, and that is not a clinical psychodrama privilege, since several emotional modalities guide professional roles in socioeducational contexts. Fears, discoveries, happiness, aspirations, affection, knowledge, theories, distress are shared in a horizontal relationship, all essential and inseparable elements from the learning process and the professional role.

Sociodrama and role-play, if used properly, can contribute to research and group conflict interventions, as expressed by Nery (2010). It also enables the study of social relationships in different contexts, trying to give a voice to all types of clientele, especially the minorities, contributing to the emancipation of the oppressed.

Finally, sociodrama and role-playing prioritize social and relational aspects without losing sight of the individual, mythological and archetypal dimension, which influences interactions and collective co-constructions. The group needs and unfolding, originated by the work within the social or educational context, are the guidelines in sociodrama, always respecting the contract and group ethics.

However, as groups take on their roles and question them, they distinguish their conflicting or imprecise functions, start to discover new creative answers for the old roles and experience new choices. They experience possibilities and telic relations and existential encounters, reverse roles and risk new ways of acting. This new perception results from the sociodramatic method and from role-playing, mobilizing transformation processes in contemporary society, which is deprived of liberating, integrating and transforming procedures.

\section{ACKNOWLEDGMENTS}

Not applicable.

\section{DATA AVAILABILITY STATEMENT}

Not applicable.

\section{FUNDING}

Not applicable.

\section{REFERENCES}

Calvente, C. (2002). O personagem na Psicoterapia: articulaçôes psicodramáticas. Ágora.

Chinen, A. B. (1989)....E foram felizes para sempre: contos de fadas para adultos. Cultrix.

Fernández, A. M. (2015). A multiplicação dramática no ensino universitário no âmbito grupal. Revista Brasileira de Psicodrama, 23(1), 23-32.

Figusch, Z. (2010). O modelo contemporâneo de sociodrama brasileiro. In: Marra, M., \& H. Fleury (Eds), Sociodrama: um método, diferentes procedimentos. Ágora.

Fox, J. (2002). O Essencial de Moreno: textos sobre psicodrama, terapia de grupo e espontaneidade. Editora Ágora.

Gasseau, M., \& Gasca, G. (Eds.). (1991). Lo Psicodrama Junghiano. Bollati Boringhieri.

Kaufman, A. (1992). O Teatro Pedagógico: bastidores da iniciação médica. Ágora.

Kesselman, H., \& Pavlovsky, E. (1989). La Multiplicación Dramatica. Ediciones Ayllu.

Knobel, A. M. (2020). Sociodrama: action mechanisms and directing strategies at two public events. Revista Brasileira de Psicodrama, 28(3), 187-197. 
Malaquias, M. C. (2007). Percurso do Psicodrama no Brasil - década de 40: o pioneirismo de Guerreiro Ramos. Revista Brasileira de Psicodrama, 15(1), 33-39.

Marra, M. M. (2004). O Agente Social que transforma: O sociodrama na organização de grupos (2nd ed.). Ágora.

Mascarenhas, P., \& Pinto, F. (1990). Psicodrama e Sociodrama: saúde mental e/ou saúde social? In Federação Brasileira de Psicodrama (Ed.), Anais do $7^{\circ}$. Congresso Brasileiro de Psicodrama. Federação Brasileira de Psicodrama.

Menegazzo, C. M, Tomasini, M. A., \& Zuretti, M. M. (1995). Dicionário de Psicodrama e Sociodrama. Ágora.

Mezher, A. (2002). A abordagem dos valores ético-culturais pelo Axiodrama. In Weil, P. (Ed.), A ética nos grupos: contribuiçôes do Psicodrama (pp.95-124). Ágora.

Moreno, J. L., \& Moreno, Z.T. (2006). Psicodrama: Terapia de ação e princípios da prática. Daimon.

Nery, M. P. (2010). Grupos e intervenções em conflito. Ágora.

Ramalho, C. M. R. (2010). Psicodrama e Psicologia Analitica: construindo pontes. Iglu.

Ramalho, C. M. R. (2016). Cores e tintas da tela psicodramática: onde Moreno e Jung se encontram. In: Gotlieb, L., \& Perazzo, S. (Eds.), Psicodrama - apontamentos e criação. Filo Czar.

Romaña, M. A. (1987). Psicodrama Pedagógico: método educacional psicodramático (2nd ed.). Papirus. 